\title{
Matthew, memory theory and the New No Quest
}

\begin{tabular}{|c|c|}
\hline \multicolumn{2}{|l|}{$\begin{array}{l}\text { Author: } \\
\text { Zeba Crook }\end{array}$} \\
\hline \multicolumn{2}{|c|}{ 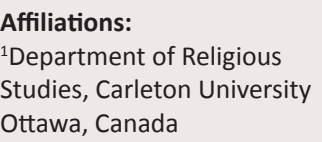 } \\
\hline $\begin{array}{l}{ }^{2} \text { Department } \\
\text { Testament Stu } \\
\text { of Theology, } \mathrm{U} \\
\text { Pretoria, Sout }\end{array}$ & $\begin{array}{l}\text { f New } \\
\text { dies, Faculty } \\
\text { niversity of } \\
\text { Africa }\end{array}$ \\
\hline \multicolumn{2}{|c|}{$\begin{array}{l}\text { Note: } \\
\text { Prof. Dr Zeba Crook is } \\
\text { a research associate of } \\
\text { Prof. Dr Ernest van Eck in } \\
\text { the Department of New } \\
\text { Testament Studies, Faculty } \\
\text { of Theology, University of } \\
\text { Pretoria, Pretoria, } \\
\text { South Africa. }\end{array}$} \\
\hline \multicolumn{2}{|c|}{$\begin{array}{l}\text { Correspondence to: } \\
\text { Zeba Crook }\end{array}$} \\
\hline \multicolumn{2}{|c|}{$\begin{array}{l}\text { Email: } \\
\text { zeba.crook@gmail.com }\end{array}$} \\
\hline \multicolumn{2}{|c|}{$\begin{array}{l}\text { Postal address: } \\
\text { 2a43 Paterson Hall, Carleton } \\
\text { University, } 1125 \text { Colonel By } \\
\text { Drive, Ottawa, ON, K1S 5B6, } \\
\text { Canada }\end{array}$} \\
\hline $\begin{array}{l}\text { Dates: } \\
\text { Received: } 07 \\
\text { Accepted: } 17 \\
\text { Published: } 20\end{array}$ & $\begin{array}{l}\text { Aay } 2014 \\
\text { uly } 2014 \\
\text { Nov. } 2014\end{array}$ \\
\hline $\begin{array}{l}\text { How to cite th } \\
\text { Crook, Z., } 201 \\
\text { memory theor } \\
\text { No Quest', HT } \\
\text { Studies/Theol } \\
70(1), \text { Art. \#27 } \\
\text { http://dx.doi.c } \\
\text { hts.v70i1.2716 }\end{array}$ & $\begin{array}{l}\text { is article: } \\
4, \text { 'Matthew, } \\
\text { y and the New } \\
\text { Teologiese } \\
\text { gical Studies } \\
16,11 \text { pages. } \\
\text { rg/10.4102/ }\end{array}$ \\
\hline $\begin{array}{l}\text { Copyright: } \\
\text { (C) 2014. The A } \\
\text { Licensee: AOSI } \\
\text { OpenJournals. } \\
\text { is licensed und } \\
\text { Creative Comn } \\
\text { Attribution Lic }\end{array}$ & $\begin{array}{l}\text { uthors. } \\
\text { S } \\
\text { This work } \\
\text { ler the } \\
\text { nons } \\
\text { ense. }\end{array}$ \\
\hline Read online: & $\begin{array}{l}\text { Scan this QR } \\
\text { code with your } \\
\text { smart phone or } \\
\text { mobile device } \\
\text { to read online. }\end{array}$ \\
\hline
\end{tabular}

This article explores the effects of cognitive and social memory theory on the quest for the historical Jesus. It is not the case that all memory is hopelessly unreliable, but it is the case that it commonly is. Memory distortion is disturbingly common, and much worse, there is no way to distinguish between memories of actual events and memories of invented events. The Gospel of Matthew was used to illustrate this very difficulty. This article also draws attention to the fact that although numerous criteria have been developed, refined and used extensively in order to distinguish between original Jesus material and later church material, those criteria have long been unsatisfactory, and most recently, because of the effects of thinking about memory theory and orality, have been revealed to be bankrupt. Since memory theory shows that people are unable to differentiate accurate memory from inaccurate and wholly invented memory, and since the traditional quest criteria do not accomplish what they were intended to, this article argues that scholarship about Jesus has been forced into a new no quest.

\section{Introduction}

I once believed, and I have taught many students, that logical, rigorous and reasonable historical criteria could be applied to the sayings of Jesus, allowing us to reverse a process of accretion, adaptation and calcification in order to arrive at sometimes more and sometimes less reliable kernels of utterances that came directly from Jesus' lips. In concert with the Jesus seminar, I was not over-optimistic about the number of these kernels: some things had been altered beyond recognition and others invented outright. In other words, when I encountered memory theory a number of years ago, I was not naïve about the outright invention of Jesus material among the earliest Christians. But I was utterly naïve about the way groups dis-remember the past. I admit I believed that the proper application of rigorous criteria could lead us to the reconstruction of the past as it actually happened.

As memory theory has entered into New Testament studies, a few shifts have emerged. There are some New Testament scholars who find in memory theory cause for confidence in the basic reliability of the Gospels (e.g. Dunn 2011; Gerhardsson 1961; Keener 2009; Le Donne 2011; McIver 2011). ${ }^{1}$ Others on the other hand are decidedly more pessimistic (e.g. Allison 2012; Duling 2011; Kelber 2006; Kloppenborg 2012; Williams 2011). I count myself, obviously, among the latter group (Crook 2012, 2013).

In defence of the former group of scholars, the transition in Memory Studies away from a default confidence in memory (or, thinking about memory as a stable process involving the straightforward retrieval of data from our memory bank) has been a gradual one (Winter 2012). What has replaced it, in so very much of the work on memory in the last 20 years, is the position that memory is not something that is retrieved but something that is reconstructed in every act of remembering. And it is in that act of reconstruction that memory is prone to failure and distortion. All memory theorists who work on distortion are quick to point out: to say that memory is prone to distortion does not mean that all memory is hopelessly distorted. But it does mean that the problem of memory distortion cannot be ignored and ought not to be minimised, which prior to 1995 it had been (Schacter 1995a). I would contend that scholars who think that memory theory confirms the reliability of the Gospels have not adequately engaged the literature on memory distortion. Having said that, one would want to make clear that there is not only one way to respond to memory distortion - namely, throwing despairing hands into the air - as can be seen in the thoughtful work of Anthony Le Donne (2011), Chris Keith (2012) and Tom Thatcher (2006), among others. But it is the case that the characteristics of memory distortion are every bit as sobering as Dale Allison (2012) has recently lamented:

\footnotetext{
1.I put these in the same group because they all attest to the basic reliability of the Gospels, even while some of them allow for
} imperfections of memory, and therefore allow for some modest degree of creativity. 
Memory is reconstructed as well as reproductive and so involves imagination. It deteriorates over time. It is typically a function of self-interest. It is sculpted by narrative conventions. It regularly moves events forward and backward in time. It is altered by post-event information. And it recurrently often assimilates to present circumstances. (p. 197)

\section{Strategies of memory distortion}

Memory distortion matters, but it took scholars a significant amount of time to come around to this fact (Roediger III 1996). This is likely because it is human tendency to trust memory: memory is so related to our perceptions of ourselves, the world around us and our place in it, that our memories normally feel strongly and reliably rooted inside us (Magnussen et al. 2007; Schacter 1996:308). Recent work in memory theory has challenged this notion.

A decade before the serious work on memory distortion began, Hobsbawm and Ranger presented a short collection of essays on the wholesale invention of tradition. The essays in this volume focused on the British Commonwealth, from Highland and Welsh culture to Indian and African colonial experiences. Together the essays reveal that time and again, from location to location, traditions 'which appear or claim to be old are often quite recent in origin and sometimes invented' (Hobsbawm \& Ranger 1983:1).

The mid-1990s brought a considerable increase in work on memory distortion (Baumeister \& Hastings 1997; Geary 1994; Loewen 1995; Roediger \& McDermott 1995; Schacter 1995b; Yapko 1994). Though not the earliest, I shall build the immediate conversation around the study by Roy Baumeister and Stephen Hastings, since it has a structure other attempts lack. Baumeister and Hastings offer a perceptive discussion of how groups distort the past. Their particular interest concerns the manner in which 'memory can be manipulated for the purpose of collective self-deception' (Baumeister \& Hastings 1997:277). Centrally important here is the agency exercised by groups in manipulating memory; this is different from accidental forgetting, which does not presume agency. This manipulation is deliberate because it is done for a purpose, usually to reflect well on the group. Baumeister and Hastings take it as axiomatic that 'most social groups wish to maintain a positive image of themselves', and I would add, of their founding figures (Baumeister \& Hastings 1997:278). ${ }^{2}$

Baumeister and Hastings represent seven strategies or mechanisms for the deliberate distortion of collective memory. In order of degree of distortion, they are:

- linking versus detachment (presenting or adhering to, or rejecting, certain causal connections between events)

- blaming the enemy (making your own misdeeds appear to be a measured reaction, for instance, rather than an over-reaction or unprovoked attack)

- blaming circumstances

- contextual framing

- selective omission of disagreeable facts

2.This same point was made by Hobsbawm, who related memory invention to the need for 'socialization, the inculcation of beliefs, value systems and conventions of behaviour' (Hobsbawm \& Ranger 1983:9).
- exaggeration and embellishment

- outright invention of false memories.

Let me discuss each of these in turn. The first four of these tend not to change the past, they merely try to alter what the past means or how it unfolded. For example, when it comes to linking versus detachment, most major events have a complex constellation of causes. When a group wishes to control how a past event is understood (e.g. the invasion of a country), they might focus on only one cause (e.g. ethics), ignoring other causes (e.g. economics), in such a way that legitimises actions perhaps they are otherwise embarrassed about. When causes and effects are detached and re-attached, distortion naturally occurs. Thus, for some groups, the invasion of a country for their oil is a sign of corruption and greed, but doing so in order to save an oppressed people from a tyrannical leader is legitimate. This form of distortion is the most mild of these forms because the past is not re-written or invented so much as it is merely 'spun'.

Another distortion strategy that does not deny a past event is one in which blame is directed at the enemy. This is commonly found in German explanations for the invasion of Russia: though Russia and Germany were, by treaty, allies, Germany often claims to have feared imminent attack from Russia, so they present their attack as justifiable, especially given their much smaller size.

If blaming the enemy is not an option, blaming circumstances might be - Baumeister's and Hasting's third strategy of memory distortion. The past event in question might still be embarrassing, but this strategy helps to shift blame away from one. Emphasising the ugliness of war and its odious collateral damage is an example of this.

Fourthly, one's context can determine how one distorts the past, since being a member of a group will outfit one with the most flattering version of events. Thus, Christians tended to remember the crusades as about freeing other Christians in Muslim lands, while Muslims have tended to remember the crusades as the first in a long line of unprovoked invasions. Clearly, the distorted memories of both groups are a symptom of their mutually exclusive contexts.

These first four strategies of memory distortion are different from the three that follow because the first four do not attempt to change the past. With strategies such as linking or detaching, blaming the enemy, blaming circumstances and contextual framing, groups accept the occurrence of an embarrassing event. They do not deny the past, but their memory distorts it in order to reduce the embarrassment, or to explain in a distorting way why the event was necessary or justified. The next three strategies are much more highly distorting because they deal with the past by actively changing it.

Selective omission, as the name suggests, involves ignoring and sometimes denying certain events or 
otherwise widely agreed-upon facts from the past. ${ }^{3}$ The frequency with which this strategy can be found in group narratives suggests it is easily executed. ${ }^{4}$ So, for instance, the collective memory of founding American figures such as Thomas Jefferson, Abraham Lincoln and Patrick Henry often omits the opinions and practices they had concerning slavery (Loewen 1995:146). Selective omission is not only a strategy of memory distortion for the American liberal left either: the American conservative right often selectively omits cameos of Jesus' excoriating wealth and helping the poor from their collective memories of Jesus (O'Reilly \& Dugard 2013). Michael Kammen (1995:333) shares this opinion about the distorting power of selective remembering: his study shows that 'memories can readily, with scant embarrassment or challenge, be quietly repressed within a generation and replaced by alternate explanations'. Distorting collective memory for reasons of nationalistic cohesion or self-confidence or flattering selfrepresentation is found in countries the world over (see the works cited in Kammen 1995:340).

Exaggeration and embellishment can be mild strategies of memory distortion, like the earlier forms of distortion. But it is not difficult to imagine instances wherein exaggeration and embellishment could be extreme enough to result in the creation of a whole new memory, or at least a memory whose relationship to the original past event all but disappears. This potential is missed by Baumeister and Hastings who limit the effects of exaggeration and embellishment. For example, crediting Christopher Columbus with 'discovering' North America when 60 million people already lived here is clearly moderately distortive. But one can just as easily exaggerate or embellish an event so extensively that it becomes a unique event. One could speculate whether something like this might stand behind some of the miracles of Jesus, wherein a few people fed as an act of radical commensality becomes a feeding of several thousand with a few loaves.

The final and most extreme strategy of memory distortion is the outright invention of memory for events that never happened. Here is where Baumeister and Hastings are least satisfactory; they offer one example only, and conclude that 'outright fabrication of collective memory is rare' (Baumeister \& Hastings 1997:282). Two features are problematic about this claim. The first concerns what is meant by 'fabrication'? As I noted earlier, at what point is a memory so thoroughly exaggerated or embellished that it becomes a new and thereby fabricated memory? The more serious problem with their claim about rarity, however, is that the outright fabrication of memory is far more common than they allow.

It is not hard to see how wrong Baumeister and Hastings were concerning the rarity of fabricated collective memory:

3.When Jan Assmann (1995:366) refers to the eradication of memory as the "most extreme form of distortion', he clearly has more in mind than merely selective omission.

4.It warrants clarifying that forgetting is not precisely the same phenomenon as selective remembering, yet it is clearly related to it. It is therefore interesting that so few address forgetting as a form of memory distortion (Esposito 2008). if nothing else, they might have considered some of the patently implausible things groups have believed over the centuries, for example, that Jewish men menstruate, that a snake spoke to the first woman, that the Torah was translated from Hebrew into Greek identically by 72 scholars in 72 days, that the world was created by the slaying of a giant serpent. The list can easily be lengthened tenfold. The study by Hobsbawm and Ranger was not missed by the various authors found in the Schacter volume (1995b), but it appears to have been missed entirely by Baumeister and Hastings, to their serious detriment. People have been deeply committed to untruth, to the utterly fantastic since the beginning of time, and they continue to be.

Michael Schudson has also contributed to the discussion of the processes and strategies of memory distortion (Schudson 1995). He offers four of them:

- distanciation

- instrumentalisation

- narrativisation

- cognitivisation and conventionalisation.

Distanciation starts with the obvious point that with time there is a loss of detail as memory grows more vague and there is a concomitant loss of emotional intensity. But Schudson (1995:350) points out that it is not all about loss. Distanciation also gives one a sense of historical perspective, an ability to view an event from multiple perspectives. In fact, historians are often 'obliged to rewrite history as social values change'. Indeed, a historian who does not write about slavery from the position that it is bad is not a historian, but merely an antiquarian, that is 'someone for whom there is no vital connection between present values and telling the story of past events', he suggests (Schudson 1993:54).

Instrumentalisation involves the use of the past for some particular purpose. First order instrumentalisation promotes a specific version of the past, while second order instrumentalisation makes use of the past without favouring any particular version. When the past is either taken over or manipulated in order to accomplish something specific, it does not even have to be the distant past. On the eve of the first Gulf War (1991), George H.W. Bush executed a policy that prohibited photographing flag-draped coffins returning deceased American soldiers. This in fact amounts to proactive memory distortion: Bush Senior felt that support for the war would suffer when Americans saw how many soldiers were dying, so he pre-emptively distorted American memory of that war.

Narrativisation occurs by necessity, since the past is most commonly packaged into:

$[A]$ narrative, a story, with a beginning, middle, and end; with an original state of equilibrium, a disruption, and a resolution; with a protagonist and obstacles in his or her way and efforts to overcome them. (Schudson 1995:355)

When the past is forced into a narrative pattern, it will need to be distorted in order to fit. And of course, the past needs 
to be made interesting, otherwise why bother remembering it? Schudson (1995) refers to the ways in which Watergate is 'remembered' differently in different narrativisations. The memory of the Washington Post journalists Woodward and Bernstein, contained in All the President's Men, depicts them as heroes instrumental in the victory of a liberal investigative press (Schudson 1995:356). The movie version of this book helped to ensure that this would become the broader collective memory of the event. Textbooks, on the other hand, present the event as a battle between the three branches of government - executive, judicial, and legislative - entirely ignoring the role of media.

Cognitivisation and conventionalisation require us to remember that humans are doing the remembering, and humans tend to remember according to conventions that are provided to them, remembering that memory, even individual memory, is social (Schudson 1995:358). People's own memories are shaped less by their actual experiences than by what they are socialised to think they are supposed to have experienced (Schachtel 1947). This applies to collective memory as well, and is aided by institutions: for something to be remembered, it has first to be remembered at all, in contrast to the myriad things not remembered at all. One form of conventionalisation is memorialisation, a process that always leaves someone feeling left out. In Canada, a plan to create a private Holocaust Museum was derailed when the Federal Government became involved and wanted to replace it with a National Museum of Human Rights. Since then, every conceivable group wants to have their tragedies represented, and those that are selected complain that the representation is insufficient, insulting, or dishonouring (Hamilton 2013). They all know, it seems, as Schudson did, that 'turning something into a monument changes the past in that very process' (Schudson 1995:359). Ann Rigney (2008) observes that:

While putting down a monument may seem like a way of ensuring long-term memory, it may in fact turn out to mark the beginning of amnesia unless the monument in question is continuously invested with new meaning. (p. 345)

It perhaps hardly needs to be pointed out that these strategies of distortion are not mutually exclusive. Consider the collective memory of Austria's role in the Holocaust. After the war, Austria was offered by the Allies - and quickly embraced - the role of first and heroic resister to Nazism. By 1955, Austria's enthusiastic embrace of Nazism and its profound role in the Holocaust were all but forgotten, as Austria was cast in the role of victim of and resister against Germany (Miller 1990:68). The distorted memory was fully in place by 1965, and was articulated in the movie The Sound of Music (1990:61-62). Here of course is an instance of memory distortion that was as much effected by instrumentalisation as it was by narrativisation. A sanitised past held a central function in many nations' desire (Austria was not the only one) to put the horrors of the Holocaust and anti-Semitism behind them. The result was a narrativisation of the past that cast Austria as victim and noble freedom fighter.
More recently in the study of memory distortion, Roediger and McDermott (2000) offer in addition six factors in the distortion of memory. They begin by suggesting that there are two general classes of errors in remembering: omission and commission. Omission is the failure to recollect a prior event when one tries to, while commission is the remembrance of events quite differently from the way they actually happened, or more seriously, 'they remember an event that never happened at all’ (Roediger \& McDermott 2000:149).

Memories of events that never happened are an upsetting and unsettling notion for many people. It contradicts our powerfully intuitive and personal experience of memory. Roediger and McDermott (2000) acknowledge this:

People would like to believe that their memories are more or less accurate renditions of the experiences that occurred to them in the past. How could a memory for an event be 'false'? Where would the recollection come from, if not from stored traces of actual events? (p. 149)

Roediger and McDermott (2000) collect six factors leading to memory distortion:

1. Relatedness effects occur when people experience a series of events that are strongly related; the relatedness of the events causes them to create memories that fit into that series but did not actually happen. This happens also when people use their general knowledge of the world to fill in gaps in their memory. Thus, when trying to recall a disjointed or meaningless series of events, people will fill in the gaps in order to introduce coherence and meaning based on what must have happened.

2. Interference effects occur when a critical event suffers interference from the memory of events just prior to (proactive interference) or just after (retroactive interference) it. Interference can also happen with the introduction of new information or the asking of leading questions - a form of contamination.

3. Effects of imagining refer to false memories one can develop by repeatedly imagining an event for which one was not present. Similarly, repeatedly imagining an event that never happened can eventually produce the memory that it did actually happen (see also Ceci 1995:97-98).

4. Retrieval and guessing effects: the act of repeatedly retrieving a false memory produces a strong cognitive sense of having been present at events people were not present at. In this instance, the person is told the memory is false, but is asked to retrieve the memory repeatedly.

5. Effects of social contexts refer to the social pressure people experience to conform to the memory of the group. One particular measure in this regard is called the 'conformity paradigm': 'the greater the number of confederates whose erroneous responses preceded that of the actual subject, the more likely the actual subject was to conform to the erroneous group judgment' (Roediger \& McDermott 2000:157).

6. Individual differences factor is very simple: some people are more susceptible than others to memory distortion, such as the very young and the very old.

Roediger and McDermott point out that people in real life situations are susceptible to many of the same effects of 
memory distortion as are people in clinical tests. Many studies show how this is so with eyewitnesses to crimes, for instance. And yet, human nature is determined to accept eyewitness testimony as reliable. ${ }^{5}$ These studies of memory distortion simply do not support such confidence (or benefit of the doubt). The same can happen with memories recovered in a variety of therapeutic environments.

\section{The unreliability of gist memory}

It is natural and common to imagine that while memory for details might weaken over time, memory for the gist of an event will be much more durable and reliable. This arises in biblical studies in the increasingly common claim that since gist memory is more reliable than detail memory, we can trust the Gospel writers to have maintained the gist of material from and about Jesus, even if minor details vary or have been lost (Bailey 1991; Dunn 2003; Keener 2009; Le Donne 2011; McIver 2011). And while it is indeed the case that the brain performs better at the level of gist memory than detailed memory, it turns out that this is not by much. Gist memory is also susceptible to memory distortion.

Consider the following studies, which though they are local are replicated countless times around the world and throughout history. Above I referred to a study of how Austrian collective memory about their national collaboration with Nazi Germany departs significantly from the well-documented historical record. The 'gist' of Austria's sanitised story is that they were Europe's first resisters of Nazi Germany's anti-Semitic views. The details of history are that Austria enthusiastically embraced Hitler's Final Solution, that three-quarter of Nazi prison camp guards were Austrian, and that Austria had more Nazi party members per capita than did Germany (Miller 1990:63-68). For several decades after the war, Austrian collective memory did not retain even the 'gist' of their actual past. That past had been distorted and forgotten to the extent that a new gist memory had taken its place. Gist memory is not less prone to the strategies and forms of distortion we saw above.

Similarly, Jan Assmann compares the way Egyptian and Ancient Israelite sources remember the encounter between the two groups in the 14th century BCE, noting how fundamentally different they are (Assmann 1995). Egyptian memory depicts the Hebrews as cruel oppressors who were an abomination to the gods. Israelite memory depicts peaceful Hebrews acting as responsible citizens until they were enslaved without cause by the evil Egyptians. Assmann's observation is that the location in which a reconstruction (or representation of the past) happens fundamentally shapes the memory, and the gist is utterly lost in the process. There is no shared 'gist' between the Egyptian and Israelite versions of this encounter. One might object that the 'gist' of the stories is that 'someone felt threatened by someone else and violence was the result' but this is so banal it surely cannot serve as the gist of this story.

5.Conversely, see Redman (2010)
Peter Burke (1989) considers historical figures to which myths adhere, and how frequently the origin of these myths is not to be found in things these people actually did. $\mathrm{He}$ writes that:

[T] he central element in the explanation of this mythogenesis is the perception (conscious or unconscious) of a 'fit' in some respect or respects between a particular individual and a current stereotype of a hero or villain - ruler, saint, bandit, witch, or whatever. (p. 104)

Figures can be naturally transformed in the process of executing this fit:

The transformation of the cold and colourless William III into the popular Protestant idol 'King Billy' can hardly be explained in terms of his own personality ... Bandits turn into Robin Hoods, robbing the rich to give to the poor. Rulers travel their kingdom in disguise to learn about the condition of their subjects. (Burke 1989:104)

In other words, groups regularly distort the 'gist' of their memories of their heroes and villains.

Finally, here is an example from the modern period and one that concerns the distortion of individual memory rather than collective memory. Stephen Ceci presents the interesting story about a 1967 Major League Baseball pitching incident that ended the career of a young promising player, and nearly killed him at the time. In 1990, upon the death of the injured player, the pitcher was interviewed, offering his recollection of that fateful game and what transpired afterwards. He recalls that, given the situation within the game, there would be no reason for a pitcher to harm or intimidate a batter, and that as a sign of his remorse, he tried to see the player immediately after the game, but only family were being admitted. Ceci points out that these two game-related memories of the pitcher are wholly inaccurate, and in addition are self-serving. In fact, the game was at a point where intimidating a good player was expected, which suggests not that the pitcher intended to harm, but that perhaps harm was a result of an aggressive play. And Ceci points out that the game happened in the evening, so a visit to the hospital immediately following was likely not even attempted. He concludes, for all that the pitcher claimed to have thought about that day many times and regretfully, 'he seems to have gotten the story wrong, not only in its peripheral details, but in its gist, its core truths' (Ceci 1995:92).

\section{Distorted versus undistorted memory}

I will avoid applying a quantifying adverb to the frequency with which memory is manufactured or heavily distorted - rarely, frequently, commonly - for two reasons. Firstly, because doing so is impossible. It is impossible to compare the number of manufactured memories people hold to the number of accurate memories in order to arrive at a ratio that is in any way meaningful. Still, I must point out that manufactured memories are maintained with far greater frequency, and with far more damaging effects, than Baumeister and Hastings (1997) care to admit. It also needs to 
be pointed out that one can acknowledge how frail and easily manipulated memory is while at the same time maintaining - with all memory theorists - that memory is often quite reliable. The second reason that attempting a quantifying adjective is to be avoided is that it misses the far more troubling point: that distinguishing between manufactured memories and accurate memories is nearly impossible. It is impossible both for the outsider attempting to distinguish between them and for the person who holds these memories.

Baumeister and Hastings suggest that groups might revise their self-appraisals in the light of facts. This can happen of course, as institutional and national apologies for slavery, war crimes and ethnic cleansing attest. But it can just as frequently happen that beliefs about the past are held to tenaciously in opposition to all known and readily accessible facts. Research into memory shows that people cannot distinguish between their own reasonably accurate memories and their own distorted or manufactured memories. ${ }^{6}$ Once memories are fitted into a coherent narrative, actual memories, distorted memories and manufactured memories become indistinguishable from one another. If this is so for the people whose memories they are, how much more challenging must it be for outside observers, or when reading a fictionalised biography, to distinguish between more and less accurate memories?

In a classic study, subjects were given a passage about a wild, stubborn, and violent girl (Sulin \& Dooling 1974). In some versions of the passage, the girl was named Helen Keller, in other versions she was called something else. The passage contained seven lines, each of which focused exclusively on Keller's behavioural issues (wild, stubborn and violent), and on how her parents coped with them. There is no reference at all to this person being deaf, mute, or blind. After a week, subjects were asked to look at seven lines and report both which lines were in what they originally read, and which lines were new. In each case, there was a new line added: 'She was deaf, dumb, and blind.' Subjects for whom the girl was named Helen Keller were significantly more likely than the other group to identify this line as having been part of the original passage, and to do so with a high degree of certainty. But of course, that line was not there, and subjects for whom the girl was named otherwise were more likely to know that.

So, Sulin and Dooling concluded that Frederick Bartlett's observations that people remember by fitting what they encounter into pre-existing schemata has been confirmed. The subjects all knew Helen Keller as having been deaf, mute and blind, so they naturally and confidently felt that the line describing her well-known condition was there all along. This happens because remembering is never a process of merely retrieving data from storage. Rather, 'information in the retrieval environment contributes to, and is often part of, the subjective experience of remembering' (Schacter 1995a:16). This explains why humans tend to have such a

6 . One ought also to avoid the facile rejoinder that since all memory is distorted there is no way to distinguish 'accurate' from 'manufactured memories'. It is certainly true that all memory is distorted, but it does not follow that all memory is equally distorted. Jan Assmann puts it best: although all memory is clearly to some degree reconstructed and reinvented, 'it is equally clear that ... some memories are more reconstructed and reinvented, it is equally clear that ... some memories are more
distorted than others and some traditions more invented than others' (Assmann distorted than
1995:366). high regard for the reliability of their memories: because we are so intertwined with the subjective experience of episodes in our lives, and therefore with our identity.

Stephen Ceci refers to a study in which children were persuaded that they had once caught their hand in a mousetrap so badly they had to go to the hospital (Ceci 1995). With repeated questioning about the event, $25 \%$ of the children concocted very coherent narratives about the experience, such that even professional psychologists who viewed videos of the accounts were unable to tell that the memories the children had were entirely manufactured. Ceci (1995:103) concludes that 'at least some of these children had come to believe that they actually experienced the fictitious events'. No less than $27 \%$ of the children refused to accept, upon debriefing, that in fact their memories were entirely false. They objected that they 'remembered' the events in question (see also the studies referred to in Schacter 1996:108-110).

Elizabeth Loftus (with various co-authors over her long career) has conducted a similar study multiple times, in which adults remember a time they were lost in a shopping mall as young children. After several retellings, many of the adult subjects started producing notably detailed accounts of this experience that they never had: the voice of the person who helped them, the feel and smell of their sweater, the relief and concern of their mother, and so on. Loftus shows time and again that we lack the ability 'to reliably distinguish between real and false memories, for without independent corroboration, such distinctions are generally not possible' (Loftus \& Pickerell 1995:725). ${ }^{7}$

Jan Assmann discusses a case in which a man's memories of spending time at Auschwitz had no basis in fact. Yet, astutely, Assmann does not call the man's autobiography a 'forgery'. These 'memories', he suggests, are central to the man's identity, in which he has constructed his experience of the world, and his sense of victimhood. Those memories explain to him who he is. This, according to Assmann (2006), shows that:

$[I] \mathrm{t}$ is possible for someone to believe in all sincerity that he has experienced something which in reality he has only read or heard about and absorbed in the course of collective communicative processes. (p. 4)

Loftus (1993) asks: 'If a memory is recovered that is not authentic, where would it come from? There are many possibilities, she concludes:

If not authentic, the memories could be due to fantasy, illusion, or hallucination-mediated screen memories, internally derived as a defense mechanism ... a mixture of borrowed ideas, characters, myths, and accounts from exogenous sources with idiosyncratic internal beliefs ... Inauthentic memories could also be externally derived as a result of unintentional implantation of suggestion by a therapist or other perceived authority figure with whom the client desires a special relationship, interest, or approval. (p. 524)

7.On the other hand Kim and Cabeza (2007) demonstrate that that neuro-correlates, mapped using f-MRIs, are different in high-confidence real memories and highconfidence false memories. For more on the ability of adults to manufacture memories see Hyman and Pentland (1996), Johnson et al. (1979), and Garry et al. (1996). 
In other words, memories can be manufactured from any number of sources, both external and internal, both accidentally and deliberately. But the most important feature of such memories is that ' $[o]$ nce activated, the manufactured memories are indistinguishable from factual memories' (Loftus 1993:524). Implanted memory in adults of a fictitious childhood event can be tenaciously maintained even in debriefing (Loftus \& Pickerell 1995:724). This is because the act of remembering is a deeply 'subjective experience'; memory carries as great an impact when it is veridical as when it is not (Dalla Barba 1993:15).

\section{Memories of Jesus in the Gospel of Matthew}

The preceding has established two features of memory: (1) that although memory is often reliable, it is also frequently unreliable and can be distorted deliberately and accidentally, to or by oneself and by others; and (2) that accurate, distorted and manufactured memories are pretty much impossible to distinguish from each other, for the person who holds the memory but even more so for the outside observers of those memories. If the New Testament Gospels are artefacts of memory, and they must surely be, then we are obligated to wonder: how might the preceding work on memory distortion affect our reading of the Gospels and the scholarly search for the historical Jesus.

Let us consider briefly the following ten episodes in Matthew: the slaughter of the innocents and the flight to and from Egypt (2:13-22); the baptism of Jesus (3:13-17); the lengthy sermon delivered on a mountain (5-7); the stilling of a storm (8:23-27); the parable of the mustard seed (13:31-32); feeding five thousand (14:13-21); the key commandments (22:34-40); the Jewish mob calling for the blood of Jesus (27:24-26); the tombs opening and the dead walking around the city of Jerusalem (27:51b-53); and finally the resurrection of Jesus (28:9-10).

Of this list, four are exclusively supernatural events: stilling the storm, feeding five thousand, the tombs opening and the resurrection. The remaining six are relatively mundane. That is to say, four of the stories likely did not occur as recorded (and possibly have no basis in reality at all), while the remaining six could be based on actual events in the life of Jesus because they represent real world experiences: persecution and flight, baptism, a speech, a parable, a key teaching and a bloodthirsty mob. These are not the only stories in the Gospel of Matthew that might be based on events from the life of Jesus, but they are representative. Here is what these stories tell us about memory distortion. It is possible that Jesus' family was forced to flee into another country because of persecution threatening their child. This happens to people everywhere. Yet the story contains patently unhistorical elements. Some these elements are mundane - that Jesus was born in Bethlehem (Brown 1993:513-16; Miller 2003:184; Vermès 2006:88); that Herod would be forced to rely solely on foreign Magi to find a child who presents such a threat to him (Miller 2003:110); and the slaughter that Matthew depicts (Brown 1993:189; Miller 2003:184; Robinson 2009:127; Vermès 2006:115). Other elements are unhistorical because they are supernatural (e.g. dreams and visions). It is worth pointing out that there is no significant scholarly disagreement here: the range of opinion is that Matthew either invented the slaughter story outright (Goulder 1974:239-241), or that he embellished it (France 1979:108-120; Hagner 1993:35). Either way, we see memory distortion at work, as presented above.

Consider the story of Jesus' baptism. It is nearly universally agreed that the historical Jesus was baptised by John the Baptist (Funk 1998:528-529; Sanders 1993:10; Theissen \& Merz 1998:212; Webb 2009:112), and yet into this likely historical event, Matthew inserts a redactional explanation (vv. 14-15) about how the Son of God came to need a baptism of repentance for the forgiveness of sins. That this section is Matthean redaction is suggested strongly by the fact that the two verses contain key theological concerns and vocabulary of Matthew (Davies \& Allison 1988:1.323; France 2007:119-120; Luz 2007:142; Turner 2008:118; Webb 2009:133, n. 129), but also and especially that we see here Matthew's solution to the theological problem posed by Jesus' baptism by John. How telling that the first words of Jesus 'remembered' by Matthew are likely Matthew's own theological invention.

Finally, let us consider the Matthean blood libel (27:24-25). ${ }^{8}$ Here is another story that could have happened, in that it is mundane, yet most scholars consider it another Matthean creation. Matthew has Pilate enact a highly symbolic and public act of washing his hands of Jesus' blood, and the Jewish crowd calls for that blood to be upon them and their children. As with the examples above, the style in this passage is uniquely Matthean, and not surprisingly few modern scholars accept the historicity of what is depicted in the insertion (Beare 1962:236; Brown 1994:833; Crossan 1995:157; Levine 2002:91; Luz 2005a, 2005b:58). ${ }^{9}$ Matthew 27:24-25 represents Matthew's escalation of his anti-Jewish polemic and his exoneration of the Romans.

These various episodes reflect many of the features of memory distortion presented above. Firstly, there are memories in Matthew that cannot have happened: the dead walking around the streets of Jerusalem, Jesus rising from the dead are two obvious Matthean examples of wholly manufactured memories, among many. Baumeister and Hastings are alone in the opinion that fabrication is rare. It is not rare, even if it is not the norm. Memories can also be manufactured in people because of what Roediger and McDermott called the 'effects of social contexts' (presented above). Any manufactured memory in Matthew has two

8.For the sake of argument, I would like to consider the Sermon on the Mount, the parable of the mustard seed (13:31-32), and the key Commandment (22:34-40) as events that go back to the life of Jesus. Though there are redactional and composition issues, they need not concern us in this context.

9.Aponizō is hapax in the New Testament; apenanti is found 2 times in Matthew, not at all in the other Synoptic Gospels (though 2 times in Acts); athōos occurs 2 times in Matthew, but not in the rest of the New Testament. 
potential sources: either the author of Matthew himself has invented it, or he inherited it from his circle. If the latter, then we have an instance of social context resulting in a distorted, or manufactured memory.

Secondly, there are memories in Matthew that were obviously significantly altered from a potential original. Matthew's theological apology for John's baptism is a powerful example. Here is an event that is almost certainly historical, yet Matthew has altered the memory in order to improve it. We might call this linking and detaching. If Jesus was originally one of John's disciples, baptised for the same reason everyone else was baptised, then it is predictable that Jesus' own followers would detach the baptism from that original explanation and attach it to another. This might also be an example of Schudson's 'instrumentalisation'. Here Matthew is using the baptism within his narrative, the point of which, as with any bios must surely be to persuade readers towards emulation. In the use of the story, theologically troublesome features get distorted. Other memories, such as the feeding of the five thousand could be an example of exaggeration and embellishment. When Matthew has Jesus ride a donkey into Jerusalem, fitting the story so perfectly that it mirrors Zechariah, this is an example of Roediger's and McDermott's 'relatedness effect'.

A third feature of these stories that is consistent with what we have seen above is the most troubling feature of all. Consider this: plenty of scholarly debates exist concerning the historical accuracy of many Matthean events, of course. This debate, however, exists not with any assistance from Matthew, but in spite of him. Without exception, each of the Matthean stories above is presented unqualifiedly as absolutely true, an actual event in the life of Jesus. Matthew does not indicate that he thinks the dead walking about Jerusalem might be less reliable a memory than Jesus' having spoken the parable of the mustard seed. There is nothing in the prose of each narrative that suggests Matthew might think differently about those two episodes. Since there is no marking by which Matthew indicates he might think some of his stories are somewhat less likely than others, on what basis can modern scholars say that the dead perambulating Jerusalem (Mt 27:54) is not likely an actual event, but the parable of the mustard seed was? Or that the parable of the mustard seed was performed by Jesus, but that Matthew 27:25 was composed by the author of Matthew? The writer of the Gospel of Matthew presents collective memories of Jesus: some of them are obviously not real. The question is: How do we tell the difference? Answered simply: we cannot tell the difference.

The writer of the Gospel of Matthew is, of course, not alone among ancient historians in maintaining, distributing and possibly inventing distorted memories. One Maccabees 12:20-23 presents evidence, in the form of a letter from the Spartan King Arias to Onias, the 4th century BCE high priest, that Spartans and Jews both descended from Abraham. While this claim is clearly fantastic, what is decidedly more interesting is that Josephus passes on this memory as history (AJ 12.225-227). That is, Josephus considers the letter historical; he does not have at his disposal the tools (or he lacks the inclination) to doubt the veracity of the claim. Earlier, Josephus reports the historical event of Alexander the Great's encounter with the Temple. Alexander, marched in anger against Jerusalem for its disloyalty, but upon coming face to face with the splendour of the high priest in the Temple, Alexander fell to his knees and wept (AJ 11.317-339). So, just as we have in Matthew, Josephus presents possibly reliable accounts of the past side-by-side with certainly unhistorical accounts, and in some instances, as in Matthew, sometimes with a considerable amount of extremely vivid detail. ${ }^{10}$

\section{Memory, criteria, and the quest}

For most of the last century of Jesus scholarship, the primary tool available to scholars for distinguishing between historically reliable and historically unreliable material was the traditional form-critical criteria developed over the new and third quests: multiple independent attestation, double dissimilarity, embarrassment, rejection, coherence and so on. But a recent and extremely important collection of essays has dismantled the usefulness of these criteria (Keith \& Le Donne 2012).

According to Keith and Le Donne, and a small group of predecessors, the traditional quest for the historical Jesus is characterised by the quest to reconstruct the original, authentic words of Jesus using criteria of which the foundation is form criticism. The foundational assumption behind form criticism is that there is a linear trajectory from a speech event originating with Jesus to the written Gospels after him, and that this trajectory involves a fairly predictable process of accretion, alteration and adaptation. Because the process is fairly predictable, criteria - such as those just mentioned can be applied to the final product in order to reverse this process of accretion, alteration and adaptation. The process having been reversed, scholars can arrive at an original core of what Jesus said, or reject the saying as unhistorical, as with the Jesus seminar.

There are multiple problems with this approach. Firstly, and most seriously, the search for one authentic form of a Jesus saying ignores that Jesus would have delivered any speech or story multiple times, and if he was any good at all at his trade, each delivery would have been a little different. Therefore, it is in fact impossible to speak of an original version, as every performance would be an original. ${ }^{11}$ Secondly, this one fact has a direct bearing on our ability to neatly separate tradition (Jesus) from interpretation (later Christians): it cannot be done. Thirdly, memory theory contributes to this particular point as well: since all remembering requires interpretation and framing, separating tradition (what is remembered) from interpretation (how it is remembered) is flatly impossible. As Keith (2012:39) observes, '[i]f not for those [interpretive] frameworks, the past would not survive at all.' Elizabeth Tonkin (1992) makes the same point when she observes that:

10.See the astute analysis of these, and other, episodes in Gruen (1993).

11.Kelber (2006:17). For more on oral tradition in the New Testament, see the new and outstanding work by Rodríguez (2013). 
Professional historians who use the recollections of others cannot just scan them for useful facts to pick out, like currants from a cake. Any such facts are so embedded in the representation that it directs an interpretation of them, and its very ordering, its plotting, and its metaphors bear meaning too. (p. 6)

Because of these issues, Keith, Le Donne and their able contributors declare the criteria approach to the Quest for the historical Jesus dead, unable to complete the task for which it was created. In other words, the criteria cannot be used to distinguish between the authentic memory which we hope and expect is in the Gospels and the manufactured or distorted memory which we know is in the Gospels. Where does that leave us? With a New No Quest.

Memory theory shows us that it is impossible to distinguish between real and distorted memories. And Keith and Le Donne show that the tools we always thought could be used for that purpose are irreparably broken. The search for authenticity was the heart of the New and Third quests for the historical Jesus, as Keith and Le Donne amply show. If the search for authentic material is no longer tenable, then there really is no more Quest. Now, there might be other enterprises, other projects relating to the study of Jesus, and some of them might be richly rewarding: the study of how Jesus was remembered, how memory of Jesus functions in the development of Christian community and memory, and so on. But it would be misleading to call any of these the Quest for the historical Jesus, as if we can take over a game, fundamentally change all of its rules, yet still pretend we are playing the same game because we keep the name. If the search for an authentic, original Jesus has been abandoned, rightfully, then really and truly there is no Quest any more. ${ }^{12}$

\section{Conclusion}

In a 2011 book on memory and the historical Jesus, Robert McIver puts on full display the frailties of human memory, making many scientific studies accessible to the reader more interested in Jesus. He is explicit about the problems involved with immediate and long-term eyewitness reliability, personal event memory, suggestibility, distortion and bias. He is also clear about the challenges posed by forgetting, memory erosion over time, and that flash-bulb memory is not, in fact, more reliable than other types of memory. The studies that McIver summarises show that human memory is reconstructed in shards, often reliably, but always with a considerable loss of detail and never recalled in a challenge-free process. Though he does have a tendency to over-emphasise reliability, he does nonetheless illustrate that memory is reconstructive rather than reproductive, in keeping with most cognitive and social-scientific research on memory.

Yet, when McIver turns from establishing the frailty of memory to the study of the Gospels, it seems that none of

12. Interestingly the suggestion that memory theory ought to move us into a new No Quest is in keeping with what occurred during the original No Quest (c. 19001950): despite being commonly known as the No Quest, there was in fact work $1950)$ : despite being commonly known as the No Quest, there was in fact work
being done on Jesus. This work was, however, more existential and theological (a being done on Jesus. This work was, however, more existential and th
la Bultmann), and was concerned less with historical reconstructions. the preceding work actually applies in any destabilising way to the Gospels. For example, McIver claims that the writer of Luke knew all of Matthew's Sondergut, as did the author of Matthew know all of Luke's. It can be inferred that McIver holds this position because memory is essentially reliable, and because remembering happens in groups, so if the author of Matthew knew material, the author of Luke must have known it as well. Why do Matthew and Luke lack some material the other has? Because, according to McIver, Luke's special material did not suit Matthew's needs, nor Matthew's special material Luke's needs. So he concludes, it is 'rather unlikely' that each did now know of the other's material. Such is the reliability of collective memory!

McIver's failure of nerve to apply the frailties of memory to the Gospels as artefacts of memory are most evident in the appendix to his book. Here McIver speculates about how many people could have been eyewitnesses to Jesus' career (any part of it), and from there how many could still be alive when the Gospels were composed. The demographics are unimportant here, and have been questioned elsewhere (Crook 2012). Of interest here is McIver's guiding assumption that eyewitnesses relate reliable memory, and the more eyewitnesses there are the more reliable the resulting memory will be. This explains why, after his demographic study, McIver would conclude that it is 'evident from the life tables [that] some surviving eyewitnesses would have been available to the Evangelists to consult had they so wished' (McIver 2011:209).

Some people persist in the naïve hope that memory theory supports the reliability of the Gospels. Memory theory, according to Keener (2009), argues that although:

$[M]$ emory can be imperfect, there are normally limits to this imperfection (i.e., they do not ordinarily involve free composition of events); even when some details are inaccurate, the 'gist' is usually accurate. (p. 145)

But there are simply too many instances involving the 'free composition of events' and others for which 'gist memory' is, as a matter of documentable fact, no more reliable than detailed memory. History and lab tests reveal this repeatedly, and they cannot be ignored.

My engagement with memory theory leads me in the opposite direction as McIver and Keener. I must reject their hopefulness, and conclude that finding the historical Jesus is hopeless. Memory does not refine our previous positivistic and form-critical criteria, allowing us better to distinguish between authentic and inauthentic Jesus material. Neither does it provide a new means by which to discover authentic Jesus material. Rather, in my opinion, memory theory pushes us ever further away from certainty, from confidence in assessing authentic material, and in distinguishing it from inauthentic material.

There are two reasons for this. The first is not merely that memory (both individual and group) is not entirely 
trustworthy, but how commonly it is untrustworthy. We know this because there are some means by which to assess the historical veracity of some sources (realism, common sense, the agenda of the author, competing versions, etc.). Seeing that some versions of a story are less reliable than others illustrates the dynamics of memory distortion.

The second reason is far more serious: accurate and inaccurate memories (or, what I have called 'manufactured memories' elsewhere) are not qualitatively different. Memory might well work most of the time (Schacter 1996:98), but it also works poorly much of the time. I must make emphatically clear that I am not claiming that memory is always hopelessly unreliable, that none of your or my memories are reliable. I am also not saying that certain things from the past cannot be known with reasonable certainty. I am saying that all we know for sure is that our memories feel real and feel reliable, but often are not. But more to the point, too often we cannot ourselves tell the difference between our own reliable and less reliable memories. It is that last point that ought to push historical Jesus scholarship to a New No Quest. Questing for the historical Jesus can no longer be done because we do not have the means for distinguishing between reliable and unreliable memory, and because the traditional criteria, relied upon for so long, are now bankrupt.

\section{Acknowledgements Competing interests}

The author declares that he has no financial or personal relationship(s) that may have inappropriately influenced him in writing this article.

\section{References}

Allison, Jr., D.C., 2012, 'It don't come easy: A history of disillusionment', in C. Keith \& A. Le Donne (eds.), Jesus, criteria, and the demise of authenticity, pp. 186-99, T\&T Clark, London.

Assmann, J., 1995,'Ancient Egyptian Antijudaism: A case of distorted memory', in D.L. Schacter (ed.), Memory distortion: How minds, brains, and societies reconstruct the past, pp. 365-76, Harvard University Press, Cambridge, MA.

Assmann, J., 2006, Religion and cultural memory, Stanford University Press, Stanford, CA.

Bailey, K.E., 1991, 'Informal controlled oral tradition and the Synoptic Gospels', Asia Journal of Theology 5 (1), 34-54.

Baumeister, R.F. \& Hastings, S., 1997, 'Distortions of collective memory: How groups flatter and deceive themselves', in J.W. Pennebaker, D. Paez \& B. Rimé (eds.) Collective memory of political events: Social psychological perspectives, pp. 277293, Erlbaum, Mahwah, NJ.

Beare, F.W., 1962, The earliest records of Jesus, Abingdon Press, New York, NY.

Brown, R.E., 1993, The birth of the Messiah: A commentary on the infancy narratives in the Gospels of Matthew and Luke, Doubleday, New York, NY.

Brown, R.E., 1994. The death of the Messiah: From Gethsemane to the grave, Doubleday, New York, NY.

Burke, P., 1989. 'History as social memory', in T. Butler (ed.), Memory: History, culture and the mind, pp. 97-113, Basil Blackwell, Oxford.

Ceci, S.J., 1995, 'False beliefs: Some developmental and clinical considerations', in D.L. Schacter (ed.), Memory distortion: How minds, brains, and societies reconstruct the past, pp. 91-125, Harvard University Press, Cambridge, MA.

Crook, Z.A., 2012, 'Memory and the historical Jesus', Biblical Theology Bulletin 42(4), 196-203. http://dx.doi.org/10.1177/0146107912461873

Crook, Z.A., 2013, 'Collective memory distortion and the quest for the historical Jesus', Journal for the Study of the Historical Jesus 11(1), 53-76. http://dx.doi. org/10.1163/17455197-01101004

Crossan, J.D., 1995, Who killed Jesus? Exposing the roots of anti-Semitism in the Gospel story of the death of Jesus, Harper, San Francisco, CA

Dalla Barba, G., 1993, 'Confabulation: Knowledge and recollective experience', Cognitive Neuropsychology 10(1), 1-20. http://dx.doi.org/10.1080/02643299308253454
Davies, W.D., \& Allison, D.C., 1988, A critical and exegetical commentary on the Gospel according to Saint Matthew, T\&T Clark, Edinburgh.

Duling, D., 2011, 'Memory, collective memory, orality and the Gospels', HTS Teologiese Studies/Theological Studies 67(1), 103-113. http://dx.doi.org/10.4102/hts. v67i1.915

Dunn, J.D.G., 2003, Christianity in the making, vol. 1: Jesus remembered, Eerdmans, Grand Rapids, MI.

Dunn, J.D.G., 2011, Jesus, Paul, and the Gospels, Eerdmans, Grand Rapids, MI.

Esposito, E., 2008, 'Social forgetting: A systems-theory approach', in A. Erll, A. Nèunning \& S.B. Young (eds.). Cultural memory studies: An international and interdisciplinary Handbook, pp. 181-189, Walter de Gruyter, Berlin.

France, R.T., 1979, 'Herod and the Children of Bethlehem', Novum Testamentum 21(2), 89-120. http://dx.doi.org/10.1163/156853679X00064

France, R.T., 2007, The Gospel of Matthew, William B. Eerdmans, Grand Rapids, MI.

Funk, R.W., 1998, The Acts of Jesus: The search for the authentic deeds of Jesus, HarperSanFrancisco, San Francisco, CA.

Garry, M., Manning, C.G., Loftus, E.F. \& Shermen, S.J., 1996, 'Imagination inflation: Imagining a childhood event inflates confidence that it occurred', Pschyonomic Bulletin and Review 3(2), 208-214. http://dx.doi.org/10.3758/BF03212420

Geary, P.J., 1994, Phantoms of remembrance: Memory and oblivion at the end of the first millennium, Princeton University Press, Princeton, NJ.

Gerhardsson, B., 1961, Memory and manuscript: Oral tradition and written transmission in Rabbinic Judaism and Early Christianity, Gleerup, Lund.

Goulder, M.D., 1974, Midrash and LECTION in Matthew, SPCK, London.

Gruen, E.S., 1993, 'Cultural fictions and cultural identity', Transactions of the American Philological Association 123, 1-14. http://dx.doi.org/10.2307/284321

Hagner, D.A., 1993, Matthew, 2 vols., Word, Dallas, TX.

Hamilton, G., 2013, 'Canada's human rights museum was meant as a unifying force, but, so far, has only inspired criticism', National Post, , viewed 30 April 2013, from http://news.nationalpost.com/2013/09/27/canadas-human-rights-museumwas-meant-as-a-unifying-force-but-so-far-has-only-inspired-criticism/

Hobsbawm, E. \& Ranger, T., 1983, The Invention of tradition, Cambridge University Press, Cambridge.

Hyman, Jr., I.E. \& Pentland, J., 1996, 'The role of mental imagery in the creation of false childhood memories', Journal of Memory and Language 35(2), 101-1 17.

Johnson, M.K., Raye, C.L., Wang, A.W. \& Taylor, T.H., 1979, 'Fact and fantasy: The roles of accuracy and variability in confusing imaginations with perceptual memory', Journal of Experimental Psychology 5(3), 229-240.

Kammen, M., 1995, 'Some patterns and meanings of memory distortion in American history', in D.L. Schacter, Memory distortion: How minds, brains, and societies reconstruct the past, pp. 329-345, Harvard University Press, Cambridge, MA

Keener, C.S., 2009, The Historical Jesus of the Gospels, William B. Eerdmans, Grand Rapids, MI.

Keith, C., 2012, 'The indebtedness of the criteria approach to form criticism and recent attempts to rehabilitate the search for an authentic Jesus', in C. Keith \& A. Le Donne (eds.), Jesus, criteria, and the demise of authenticity, pp. 25-48, T\&T Clark, London.

Keith, C. \& Le Donne, A. (eds.), 2012, Jesus, criteria, and the demise of authenticity, T\&T Clark, London.

Kelber, W.H., 2006, 'The generative force of memory: Early Christian traditions as processes of remembering', Biblical Theology Bulletin 36(1), 15-22. http://dx.doi. org $/ 10.1177 / 01461079060360010301$

Kim, H. \& Cabeza, R., 2007, 'Trusting our memories: Dissociating the neural correlates of confidence in veridical versus illusory memories', The Journal of Neuroscience 27(45), 12190-12197. http://dx.doi.org/10.1523/JNEUROSCI.3408-07.2007

Kloppenborg, J.S., 2012, 'Memory, performance, and the sayings of Jesus', Journal for the Study of the Historical Jesus 10(2), 97-132. http://dx.doi. org/10.1163/174551912X640203

Le Donne, A., 2011, Historical Jesus: What can we know and how can we know it? Eerdmans, Grand Rapids, MI.

Levine, A-J., 2002, 'Matthew, Mark, and Luke: Good news or bad?,' in P. Fredriksen \& A. Reinhartz (eds.), Jesus, Judaism, and Christian Anti-Judaism, pp. 77-98, Westminster John Knox Press, Louisville, KY.

Loewen, J.W., 1995, Lies my teacher told me: Everything your American history textbook got wrong, Simon and Schuster, New York, NY.

Loftus, E.F., 1993, 'The reality of repressed memories', American Psychologist 48(5), 518-537. http://dx.doi.org/10.1037/0003-066X.48.5.518

Loftus, E.F. \& Pickerell, J.E., 1995, 'The formation of false memories', Psychiatric Annals 25(12), 720-725. http://dx.doi.org/10.3928/0048-5713-19951201-07

Luz, U., 2005a, Matthew 21-28: A commentary, H. Koester (ed.), transl. J.E. Crouch, Fortress Press, Minneapolis, MN.

Luz, U., 2005b, Studies in Matthew, Eerdmans, Grand Rapids, MI.

Luz, U., 2007, Matthew 1-7: A commentary, H. Koester (ed.), transl. J.E. Crouch , Fortress Press, Minneapolis, MN.

Magnussen, S., Endestad, T., Koriat, A. \& Helstrup, T., 2007, 'What do people believe about memory and how do they talk about memory?', in S. Magnussen \& T. Helstrup (eds.), Everyday Memory, pp. 5-25, Psychology Press, New York, NY

Mclver, R.K., 2011, Memory, Jesus, and the Synoptic Gospels, Society of Biblical Literature, Atlanta, GA. 
Miller, J., 1990, One, by one, by one: Facing the Holocaust, Simon and Schuster, New York, NY.

Miller, R.J., 2003, Born Divine: The births of Jesus and other Sons of God, Polebridge Santa Rosa, CA.

O'Reilly, B. \& Dugard, W., 2013, Killing Jesus: A history, Henry Holt and Co., New York, NY.

Redman, J.C.S., 2010, 'How accurate are eyewitnesses? Bauckham and the eyewitnesses in light of psychological research', Journal of Biblical Literature 129(1), 177-197.

Rigney, A., 2008, 'The dynamics of remembrance: Texts between monumentality and morphing', in A. Erll, A. Nèunning \& S.B. Young (eds.), Cultural Memory Studies: An international and interdisciplinary handbook, pp. 345-353, Walter de Gruyter, Berlin.

Robinson, B.P., 2009, 'Matthew's nativity stories: Historical and theological questions for today's readers', in J. Corley (ed.), New Perspectives on the Nativity, pp. 110131, T\&T Clark International, London.

Rodríguez, R., 2013, Oral tradition and the New Testament: A guide for the perplexed, T\&T Clark, London.

Roediger, H.L. \& McDermott, K.B., 1995, 'Creating false memories: Remembering words not presented in lists', Journal of Experimental Psychology: Learning, Memory, and Cognition 21(4), 803-814. http://dx.doi.org/10.1037/02787393.21.4.803

Roediger, H.L. \& McDermott, K.B., 2000,'Distortions of memory', in E. Tulving \& F.I.M Craik (eds.), The Oxford handbook of memory, pp. 149-162, Oxford University Press, New York, NY.

Roediger III, H.L., 1996, 'Memory illusions', Journal of Memory and Language 35(2), 76-100. http://dx.doi.org/10.1006/jmla.1996.0005

Sanders, E.P., 1993, The historical figure of Jesus, Penguin, London.

Schachtel, E.G., 1947, 'On memory and childhood amnesia', Psychiatry 10(1), 1-26.

Schacter, D.L., 1995a,'Memory distortion: History and current status', in D.L. Schacter (ed.), Memory distortion: How minds, brains, and societies reconstruct the past pp. 1-43, Harvard University Press, Cambridge, MA.
Schacter, D.L. (ed.), 1995b, Memory distortion: How minds, brains, and societies reconstruct the past, Harvard University Press, Cambridge, MA.

Schacter, D.L., 1996, Searching for memory: The brain, the mind, and the past, Basic Books, New York, NY.

Schudson, M., 1993, Watergate in American memory: How we remember, forget, and reconstruct the Past, Basic Books, New York, NY.

Schudson, M., 1995, 'Dynamics of distortion in collective memory', in D.L. Schacter (ed.), Memory distortion: How minds, brains, and societies reconstruct the past, pp. 346-64, Harvard University Press, Cambridge, MA.

Sulin, R.A. \& Dooling, D.J., 1974, 'Intrusion of a thematic idea in retention of prose', Journal of Experimental Psychology 103(2), 255-262. http://dx.doi.org/10.1037/ h0036846

Thatcher, T., 2006, Why John Wrote a Gospel: Jesus - Memory - History, Westminster John Knox, Louisville, KY.

Theissen, G. \& Merz, A., 1998, The historical Jesus: A comprehensive guide, transl. J. Bowden, Fortress Press, Minneapolis, MN.

Tonkin, E., 1992, Narrating our pasts: The social construction of oral history, Cambridge University Press, Cambridge. http://dx.doi.org/10.1017/CBO9780511621888

Turner, D.L., 2008, Matthew, Baker Academic, Grand Rapids, MI.

Vermès, G., 2006, The Nativity: History \& legend, Doubleday, New York, NY.

Webb, R.L., 2009, 'Jesus' Baptism by John: Its historicity and significance', in D.L. Bock \& R.L. Webb (eds.), Key events in the life of the historical Jesus, pp. 95-150, Eerdmans, Grand Rapids.

Williams, R., 2011, 'BTB readers' guide: Social memory', Biblical Theology Bulletin 41, 189-200. http://dx.doi.org/10.1177/0146107911423080

Winter, A., 2012, Memory: Fragments of a modern history, University of Chicago Press, Chicago.

Yapko, M., 1994, Suggestions of abuse, Simon \& Schuster, New York. 